\title{
A MORPHOMETRIC ANALYSIS OF HYLARANA SIGNATA GROUP (PREVIOUSLY KNOWN AS RANA SIGNATA AND RANA PICTURATA) OF MALAYSIA
}

\author{
RAMLAH ZAINUDIN \\ Department of Zoology, Faculty of Resource Science and Technology, Universiti Malaysia Sarawak, \\ 94300, Kota Samarahan, Sarawak, Malaysia \\ zramlah@frst.unimas.my \\ SITI NURLYDIA SAZALI \\ Department of Zoology, Faculty of Resource Science and Technology, Universiti Malaysia Sarawak, \\ 94300, Kota Samarahan, Sarawak, Malaysia \\ ssnurlydia@frst.unimas.my
}

\begin{abstract}
A study on morphometrical variations of Malaysian Hylarana signata group was conducted to reveal the morphological relationships within the species group. Twenty-seven morphological characters from 18 individuals of $H$. signata and $H$. picturata were measured and recorded. The numerical data were analysed using Discriminant Function Analysis in SPSS program version 16.0 and UPGMA Cluster Analysis in Minitab program version 14.0. The results show the complexity clustering between the examined species that might be due to ancient polymorphism of the lineages or cryptic species within the group. Hence, further study should include more representatives in order to fully elucidate the morphological relationships of $H$. signata group.
\end{abstract}

Keywords: Hylarana signata; morphometric; cryptic species; cluster analysis.

\section{Introduction}

Hylarana signata and $H$. picturata are two frog species in the Hylarana signata group that is still not well-understood where the body measurement is generally less than $50 \mathrm{~mm}$ for males and less than $70 \mathrm{~mm}$ for females, respectively. H. signata was initially described as Polypedatus signatus (type locality Matang Sarawak) ${ }^{1}$ before recognised as Rana signata $^{2,3}$. Ref. 4 however re-identified the species as Rana (Pulchrana) signata based on morphological characters and later to Pulchrana signata based on both molecular and morphological data ${ }^{5}$ in which recently, classified as Hylarana signata ${ }^{6}$. Distributions of H. signata include Peninsular Thailand and Malaysia, Sumatra (Indonesia) and also Malaysian Borneo ${ }^{7,8}$. 